Zeszyty Naukowe Szkoły Głównej Gospodarstwa Wiejskiego w Warszawie Problemy Rolnictwa Światowego tom 17 (XXXII), zeszyt 2, 2017: 287-297

DOI: $10.22630 /$ PRS.2017.17.2.46

Katarzyna Utnik-Banaś

Uniwersytet Rolniczy w Krakowie

\title{
Zmienność cen mięsa kurcząt brojlerów w krajach Unii Europejskiej w latach 2007-2016
}

\section{Variability of Broiler Chicken Prices in European Union Countries in the Period 2007-2016}

\begin{abstract}
Synopsis. Celem pracy była analiza zmienności cen mięsa kurcząt brojlerów w krajach UE w latach 2007-2016. Określono odpowiednie statystyki opisowe oraz przeprowadzono dekompozycję szeregu czasowego cen. Wielkość produkcji mięsa kurcząt brojlerów w UE w 2007 roku wynosiła 8,76 mln ton i w wzrosła do poziomu $10,98 \mathrm{mln}$ ton w 2014r. Największymi producentami w UE w 2014 roku były: Polska (14,9\% udziału w produkcji kurcząt brojlerów w UE), Wielka Brytania (13,1\%), Hiszpania $(11,2 \%)$, Francja $(10,0 \%)$ oraz Niemcy $(9,4 \%)$. Najwyższe ceny występowały w Niemczech, Finlandii i na Cyprze, a najniższe w Polsce, Wielkiej Brytanii i Bułgarii. Większe zróżnicowanie cen występowało w krajach, gdzie poziom cen był niższy, zaś w krajach o wysokim poziomie cen - ceny odznaczały się większą stabilnością. Ceny mięsa kurcząt brojlerów w UE cechuje sezonowość. Wyższe są latem, a niższe - późną jesienią i zimą. Kraje o największych amplitudach zmian sezonowych to: Polska (średnio 20\%), Portugalia (15\%), Belgia (11\%) i Wielka Brytania $(10 \%)$.
\end{abstract}

Słowa kluczowe: kurczęta brojlery, wahania sezonowe, zmienność cen

\begin{abstract}
The article presents analysis of price variability of broiler chicken meat in EU countries in period 2007-2016. Descriptive statistics were calculated and decomposition of time series of prices were performed. The production of meat broiler chicken in EU in year 2007 amounted 8, 76 million ton and increased to the level of 10,98 million ton in year 2014. The biggest producers in year 2014 were: Poland (14,9\%), Great Britain (13,1\%), Spain $(11,2 \%)$, France $(10,0 \%)$ and Germany $(9,4 \%)$. The highest prices were in: Germany, Finland, Cyprus and the lowest in: Poland, Great Britain and Bulgaria. Variability of prices was higher in countries with lower level of prices while in countries where prices were higher, they were also more stable. Prices of broiler chickens in EU are distinguished by seasonality. Higher prices are in summer and lower in late autumn and winter. Countries with highest seasonal changes are as follows: Poland (20\% in average), Portugal (15\%), Belgium (11\%) and Great Britain (10\%).
\end{abstract}

Key words: broiler chickens, seasonal fluctuations, price variability

\section{Wstęp}

Zmienność cen jest efektem zachodzących procesów rynkowych, kształtujących zmiany zarówno po stronie popytu, jak i podaży. Ceny produktów rolnych często charakteryzują się znaczną zmiennością ze względu na relatywnie większą elastyczność cenową podaży niż popytu (Hamulczuk i Rembisz, 2008). Z punktu widzenia ryzyka cenowego istotny jest charakter wahań, amplituda i zakres czasu, w jakim te zmiany

${ }^{1}$ dr inż., Instytut Ekonomiki i Zarządzania Przedsiębiorstwami, Uniwersytet Rolniczy w Krakowie, al. Mickiewicza 21,31-120 Kraków e-mail: rrbanas@cyf-kr.edu.pl 
następują. Występujące regularnie zmiany sezonowe czy długookresowe trendy pozwalają na ich uwzględnienie w procesie podejmowania decyzji przez producentów żywca drobiowego. Ryzyko stanowią natomiast krótkotrwałe wahania losowe oraz zmiany średniookresowe o dużym odchyleniu od przewidywanego poziomu cen. Problematyką zmienności cen oraz relacji cen w rolnictwie zajmowali się między innymi: Olszańska (2009); Borkowski i Krawiec (2009); Figiel i inni (2012); Szymańska (2012); Czyżewski i Kryszak (2015); Kłusek (2015).

Szczególne miejsce wśród produktów rolnych zajmuje mięso drobiowe, którego produkcja wykazuje od wielu lat dynamiczny wzrost. Według szacunków FAO, produkcja drobiarska jest około pięć razy wyższa niż 50 lat temu, na świecie jest ponad 23 biliony sztuk drobiu, co daje około 3 sztuk na osobę (Mottet i Tempio, 2017). Średni roczny wzrost produkcji mięsa drobiowego wynosił $5 \%$, podczas gdy tylko $1,5 \%$ dla wołowiny, $3,1 \%$ dla wieprzowiny, a $1,7 \%$ dla mięsa $\mathrm{z}$ małych przeżuwaczy. Walory odżywcze mięsa drobiowego i jego względnie niska cena powodują, że spożycie mięsa w Polsce wciąż wzrasta, w odróżnieniu od pozostałych gatunków mięsa. Czynnikiem sprzyjającym rozwojowi produkcji jest także wysoki poziom eksportu (ponad jedna trzecia krajowej produkcji w 2015 roku) będący efektem niskiej ceny i wysokiej jakości polskiego drobiu (Dybowski, 2015).

Celem pracy była ocena zmienności cen mięsa kurcząt brojlerów w poszczególnych krajach Unii Europejskiej w latach 2007-2016.

\section{Materiał i metody badań}

Materiał badawczy stanowiły miesięczne szeregi czasowe cen mięsa kurcząt brojlerów w poszczególnych krajach Unii Europejskiej w latach 2007-2016 pozyskane ze Zintegrowanego Systemu Rolniczej Informacji Rynkowej (2017). Informacje dotyczące rocznej wielkości produkcji pochodziły z bazy danych Faostat (2017) (ostatnie dane obejmowały lata 2007-2014).

Zakres zmienności cen w skali roku przedstawiono za pomocą: wartości średniej, współczynnika zmienności, stosunku ceny maksymalnej do minimalnej oraz maksymalnej miesięcznej zmiany cen (wzrostu lub spadku). W celu określenia rodzaju zachodzących zmian w latach 2007-2016 przeprowadzono dekompozycje szeregu czasowego cen miesięcznych $\mathrm{w}$ tym okresie.

W szeregu czasowym wyróżnić można następujące składowe (Stańko, 2013):

- Tendencję rozwojową $(\mathrm{T})$ - ujawniającą się poprzez systematyczne, jednokierunkowe zmiany (wzrost lub spadek) ceny $\mathrm{w}$ długim okresie. Jest rozpatrywana jako efekt oddziaływania stałego zestawu czynników, ma zwykle charakter trwały a odwrócenie jej kierunku wynika z zaistnienia nowych czynników długookresowych.

- Cykliczność (C) - wyrażającą się w regularnym powtarzaniu pewnego schematu wokół tendencji rozwojowej, przy czym okres wahań jest dłuższy od jednego roku. Cykliczność wywołana jest zmieniającymi się warunkami ekonomicznymi, związanymi z cyklami koniunkturalnymi w gospodarce.

- Wahania sezonowe (S) - są wahaniami wartości obserwowanej zmiennej (ceny) wokół tendencji rozwojowej i powtarzają się w przedziale czasu nie przekraczającym jednego roku. 
- Wahania przypadkowe - (I) zawsze występują jako komponent szeregów czasowych i są wywoływane przez czynniki losowe, często jednorazowe, bardzo trudne do przewidzenia.

Pomiędzy dwiema pierwszymi składowymi tj. tendencją rozwojową (T) i cyklicznością (C) występują wzajemne zależności kształtowane przez podobne czynniki. Z tego względu $\mathrm{w}$ pracy te składowe szeregu czasowego cen potraktowano łącznie jako wspólny składnik trend-cykl $\left(\mathrm{T}_{\mathrm{t}} \mathrm{C}_{\mathrm{t}}\right)$. Po wstępnej analizie danych oraz na podstawie literatury dotyczącej podobnych badań (Hamulczuk i Stańko, 2009; Idzik, 2009) do opisu szeregu czasowego cen mięsa kurcząt brojlerów zastosowano model multiplikatywny opisany formułą (Stańko, 2013):

$$
Y_{t}=T_{t} C_{t} S_{t} I_{t}
$$

gdzie: $Y_{t}-$ cena żywca $w$ czasie $t$,

$\mathrm{T}_{t} \mathrm{C}_{t}$ - trend długookresowy i wahania cykliczne,

$\mathrm{S}_{\mathrm{t}}-$ wahania sezonowe,

$\mathrm{I}_{\mathrm{t}}$ - wahania przypadkowe.

Wskaźniki sezonowości określono za pomocą metody Census II/X11. Zaletą metody Census II/X11 jest między innymi możliwość szacowania wahań sezonowych dla każdego roku oddzielnie, co pozwala na analizę ewentualnych zmian wzorców sezonowości w dłuższych okresach.

W celu sprawdzenia istotności wahan sezonowych w poszczególnych krajach UE wykonano analizę wariancji dla wartości wskaźników w poszczególnych miesiącach wykorzystując test $\mathrm{F}$. Wpływ poszczególnych komponentów szeregu czasowego, takich jak: sezonowość (S), wahania przypadkowe (I) oraz tendencji rozwojowej (TC) na ogólną zmienność cen mięsa brojlerów określono $\mathrm{w}$ zależności od czasu trwania zmian. $\mathrm{W}$ tym celu analizowano udział wariancji poszczególnych komponentów szeregu w wariancji całkowitej cen. Obliczenia wykonano za pomocą pakietu analizy szeregów czasowych i prognozowania zawartego w programie Statistica 12.0 (Kot i in., 2011).

\section{Wyniki}

Wielkość produkcji mięsa drobiowego w Unii Europejskiej wynosiła 8756,1 tys. ton w 2007 roku. Największy udział w produkcji miały: Wielka Brytania (14,5\%), Hiszpania $(12,9 \%)$, Francja $(10,5 \%)$, Polska $(10,2 \%)$ oraz Włochy $(8,4 \%)$ (rys. 1). W 2014 roku poziom produkcji wzrósł do 10983,4 tys. ton, a największymi producentami były: Polska $(14,9 \%)$, Wielka Brytania $(13,1 \%)$, Hiszpania $(11,2 \%)$, Francja $(10,0 \%)$ oraz Niemcy $(9,4 \%)$. Niewielki udział (poniżej 1\%) w globalnej produkcji mięsa brojlerów kurzych w Unii Europejskiej zajmują: Luxemburg, Malta, Estonia, Łotwa, Cypr, Słowenia, Chorwacja oraz Litwa.

Średnie ceny mięsa brojlerów kurzych w UE w 2007 roku kształtowały się na poziomie 176 Euro/100 kg (rys. 2). Najwyższe ceny występowały: w Niemczech (219 Euro/100kg), na Cyprze (218), we Francji (204) i Włoszech (197), natomiast najniższe w: Polsce (134), Bułgarii (137) i Wielkiej Brytanii (146). W dziesięcioletnim okresie ceny w UE nieznacznie wzrosły do poziomu 178 Euro/100 kg w 2016 roku. Największy wzrost cen 
miał miejsce w Szwecji (o 49\%), Danii (40\%), na Malcie (32\%) i w Finlandii (32\%). Największy spadek cen wystapił na Węgrzech (20\%), w Portugalii (18\%), Rumunii (15\%), Hiszpanii (14\%) oraz w Polsce (11\%).

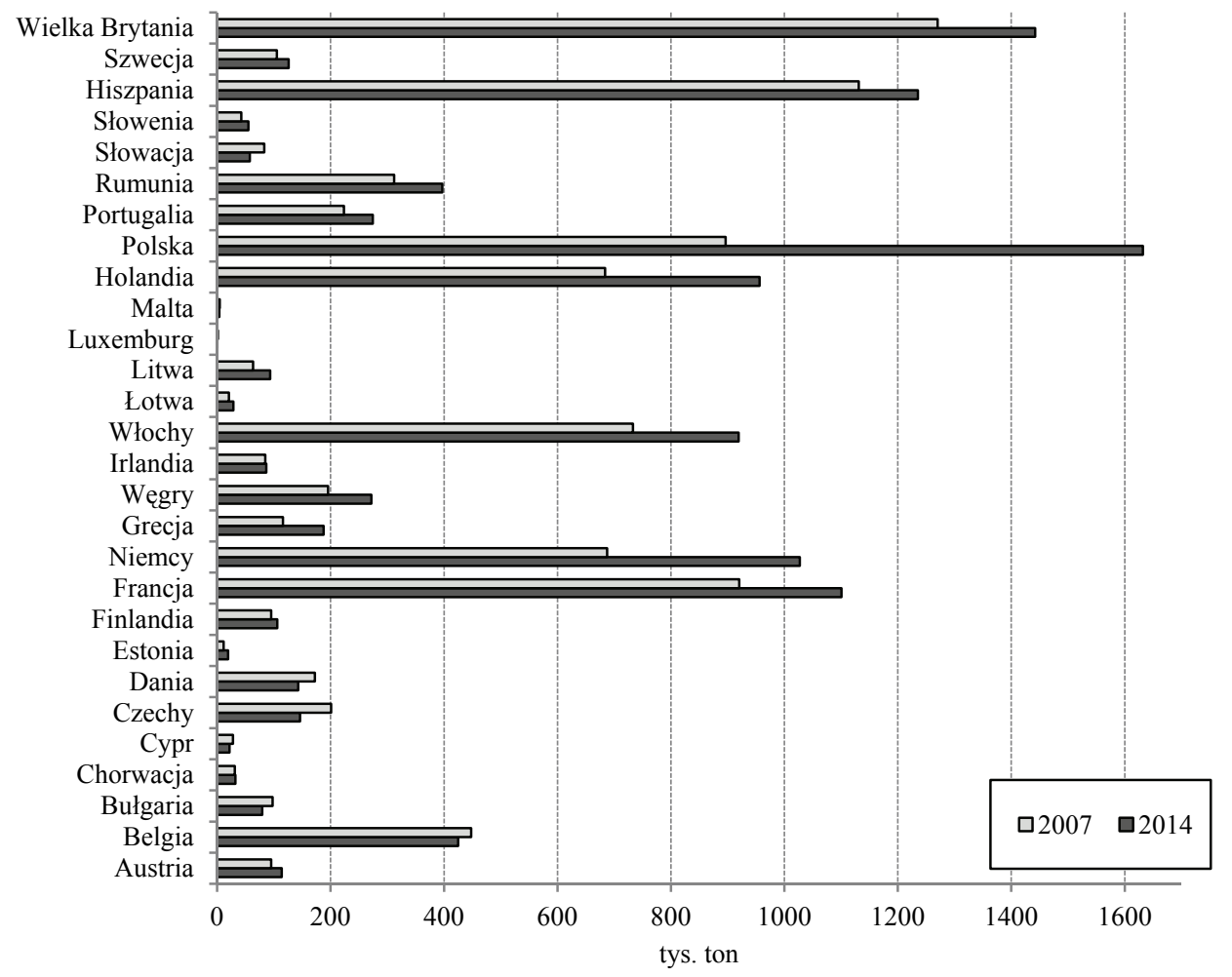

Rys. 1. Wielkość produkcji mięsa kurcząt brojlerów w wybranych krajach UE w latach 2007 i 2014

Fig. 1. Level of broiler chicken meat production in EU countries in years 2007 and 2014

Źródło: FAOSTAT 2017.

Współczynnik zmienności cen $\mathrm{w}$ skali roku $\mathrm{w}$ UE roku wynosił średnio w analizowanym okresie 3\% (tab. 1). Największą zmiennością charakteryzowały się ceny w Portugalii $(8,4 \%)$, Polsce $(7,4 \%)$ i we Włoszech $(7,2 \%)$. Maksymalne miesięczne zmiany cen w tych krajach często przekraczały $10 \%$, a stosunek ceny maksymalnej do minimalnej w skali roku oscylował wokół 1,3. Najbardziej stabilne ceny były na Malcie i w Niemczech, gdzie zarówno współczynniki zmienności jak i maksymalne miesięczne zmiany cen oscylowały wokół $2 \%$, a stosunek ceny maksymalnej do minimalnej w ciagu roku był bliski jedności (1,05-1,06). Zbliżone wyniki zakresu zmienności cen uzyskał Kłusek (2015), który analizował szeregi czasowe cen tuszek kurcząt brojlerów w odstępach tygodniowych w okresie 2009-2015 w wybranych krajach UE.

Wyniki analizy występowania sezonowości cen mięsa brojlerów kurzych w poszczególnych krajach UE przedstawiono w tabeli 2. Wysokie wartości testu F dla szeregu czasowego cen ogółem w UE $(39,95)$ potwierdzają wysoce statystycznie 
$(\mathrm{p}<0,0001)$ istotność wahań sezonowych cen na rynku Wspólnoty. Najbardziej istotne zmiany sezonowe cen miały miejsce w Polsce $(\mathrm{F}=38,27)$, Holandii $(16,60)$, Belgii $(12,52)$, Wielkiej Brytanii $(10,23)$ i Niemczech $(9,74)$. Nie zaobserwowano natomiast istotnych zmian sezonowych cen na Cyprze, Litwie, w Danii, Austrii, Słowacji, Szwecji oraz Bułgarii, co potwierdzają niskie, bliskie jedności, wartości testu F.

Tabela 1. Statystyki opisowe zmienności cen mięsa kurcząt brojlerów w krajach Unii Europejskiej w okresie 2007-2016

Table 1. Descriptive statistics of price variability of broiler chicken meat in UE countries in period 2007-2016

\begin{tabular}{|c|c|c|c|c|c|c|}
\hline \multirow[b]{2}{*}{ Kraj } & \multicolumn{2}{|c|}{ Cena } & \multirow{2}{*}{$\begin{array}{c}\text { Współczynnik } \\
\text { zmienności } \\
\%\end{array}$} & \multicolumn{2}{|c|}{ Maksymalny miesięczny } & \multirow{2}{*}{$\begin{array}{l}\text { Wskaźnik } \\
\text { zmian } \\
2007=1\end{array}$} \\
\hline & $\begin{array}{l}\text { średnia } \\
€ / 100 \mathrm{~kg}\end{array}$ & $\max / \min$ & & $\begin{array}{c}\text { spadek } \\
\%\end{array}$ & $\begin{array}{c}\text { wzrost } \\
\%\end{array}$ & \\
\hline Austria & 185 & 1,09 & 2,19 & $-4,18$ & 8,28 & 0,99 \\
\hline Belgia & 170 & 1,17 & 4,56 & $-7,74$ & 6,73 & 1,02 \\
\hline Bułgaria & 149 & 1,18 & 5,09 & $-7,55$ & 7,35 & 1,23 \\
\hline Cypr & 240 & 1,09 & 2,67 & $-2,98$ & 6,29 & 1,26 \\
\hline Czechy & 180 & 1,14 & 4,13 & $-2,71$ & 3,24 & 1,38 \\
\hline Dania & 223 & 1,14 & 3,89 & $-5,58$ & 7,27 & 1,52 \\
\hline Finlandia & 243 & 1,09 & 2,68 & $-3,82$ & 5,35 & 1,31 \\
\hline Francja & 214 & 1,10 & 3,28 & $-4,07$ & 5,36 & 1,24 \\
\hline Grecja & 206 & 1,10 & 3,02 & $-4,36$ & 4,45 & 1,09 \\
\hline Hiszpania & 176 & 1,24 & 6,36 & $-7,99$ & 9,96 & 0,96 \\
\hline Holandia & 186 & 1,16 & 4,41 & $-3,85$ & 4,85 & 1,13 \\
\hline Litwa & 169 & 1,17 & 4,70 & $-7,71$ & 9,12 & 1,02 \\
\hline Malta & 202 & 1,05 & 1,78 & $-1,98$ & 2,60 & 1,38 \\
\hline Niemcy & 250 & 1,06 & 2,25 & $-1,66$ & 2,26 & 1,38 \\
\hline Polska & 132 & 1,27 & 7,44 & $-9,89$ & 10,31 & 0,90 \\
\hline Portugalia & 162 & 1,33 & 8,43 & $-12,27$ & 17,16 & 1,00 \\
\hline Rumunia & 165 & 1,16 & 4,62 & $-6,99$ & 7,53 & 0,90 \\
\hline Słowenia & 194 & 1,10 & 3,14 & $-4,65$ & 5,27 & 1,12 \\
\hline Słowacja & 185 & 1,17 & 4,41 & $-7,86$ & 9,47 & 1,00 \\
\hline Szwecja & 222 & 1,20 & 5,48 & $-6,93$ & 12,27 & 1,48 \\
\hline Węgry & 171 & 1,13 & 3,72 & $-6,64$ & 5,77 & 0,83 \\
\hline Wielka Brytania & 147 & 1,14 & 4,44 & $-6,73$ & 6,95 & 1,12 \\
\hline Włochy & 207 & 1,27 & 7,22 & $-9,93$ & 11,01 & 1,04 \\
\hline EU & 182 & 1,09 & 3,00 & $-2,39$ & 2,20 & 1,10 \\
\hline
\end{tabular}

Źródło: obliczenia własne na podstawie danych: (Zintegrowany ... 2017). 


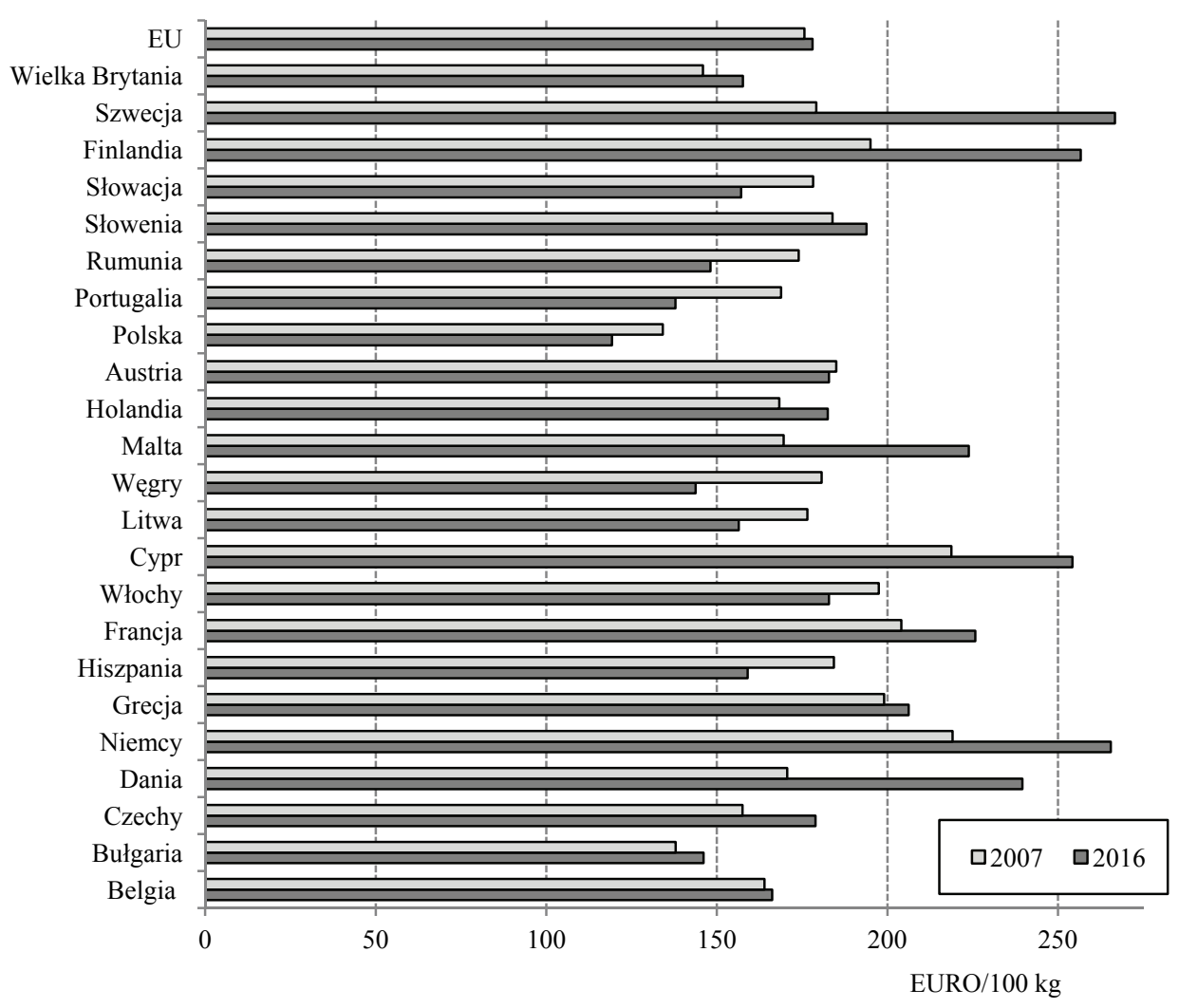

Rys. 2. Ceny mięsa brojlerów kurzych w krajach Unii Europejskiej w latach 2007 i 2016

Fig. 2. Prices of broiler chicken meat in EU Countries in years 2007 and 2016

Źródło: obliczenia własne na podstawie danych: (Zintegrowany..., 2017).

Na ogół wyższe ceny występowały w miesiącach letnich, a niższe w zimowych. W 2007 roku zakres zmian sezonowych ogółem w UE wynosił 6,5\% przy czym najwyższe ceny były w sierpniu (103,6\%), a najniższe w lutym (97,1\%) (rys. 3.). Amplituda zmian sezonowych w krajach o istotnych zmianach sezonowych była znacznie wyższa, przyjmując najwyższe wartości w Polsce $(22,8 \%)$, Portugalii $(14,9 \%)$, Wielkiej Brytanii $(13,1 \%)$, Belgii $(11,8 \%)$ i Węgrzech (10,9\%) (tab 2). W ciagu 10 lat wzorzec sezonowości cen w UE uległ pewnej zmianie polegającej na przesunięciu kulminacji cen z sierpnia na czerwiec oraz zmniejszeniu amplitudy zmian w ciagu roku do 4,5\% (rys. 4). W 2016 roku największe amplitudy zmian sezonowych cen miały miejsce: w Polsce $(17,7 \%)$, Portugalii (15,7\%), Włoszech (13,9\%), Belgii (10,8\%) i Hiszpanii (10,3\%). Pomimo dominującego w Unii Europejskiej trendu zmniejszania się zakresu zmian sezonowych amplituda tych zmian istotnie wzrosła we Włoszech, Hiszpanii i Portugalii. 
Tabela 2. Zakres zmian sezonowych cen mięsa brojlerów kurzych w wybranych krajach UE w latach 2007 i 2016 Table 2. Seasonal fluctuation of broiler chicken meat prices in EU Countries in years 2007, 2016

\begin{tabular}{|c|c|c|c|c|c|c|}
\hline \multirow{3}{*}{ Kraj } & \multicolumn{4}{|c|}{ Zmiany sezonowe w \% } & \multirow{3}{*}{ Test F } & \multirow{3}{*}{ Poziom P } \\
\hline & \multicolumn{2}{|c|}{ minimalna } & \multicolumn{2}{|c|}{ maksymalna } & & \\
\hline & 2007r. & 2016r. & 2007r. & $2016 \mathrm{r}$. & & \\
\hline Belgia & 92,8 & 93,8 & 104,6 & 104,6 & 12,52 & 0,0001 \\
\hline Czechy & 98,7 & 98,6 & 102,0 & 100,6 & 2,43 & 0,01 \\
\hline Francja & 96,0 & 98,9 & 103,1 & 100,7 & 2,48 & 0,008 \\
\hline Hiszpania & 94,8 & 94,0 & 103,7 & 104,3 & 2,86 & 0,01 \\
\hline Holandia & 96,1 & 97,5 & 103,8 & 102,1 & 16,60 & 0,0001 \\
\hline Niemcy & 96,9 & 99,3 & 102,2 & 100,6 & 9,74 & 0,0001 \\
\hline Polska & 88,5 & 92,4 & 111,3 & 110,1 & 38,27 & 0,0001 \\
\hline Portugalia & 92,7 & 93,5 & 107,6 & 109,2 & 5,22 & 0,0001 \\
\hline Rumunia & 95,1 & 97,0 & 104,6 & 103,4 & 7,83 & 0,0001 \\
\hline Węgry & 94,9 & 98,5 & 105,8 & 102,5 & 5,21 & 0,0001 \\
\hline Włochy & 92,5 & 93,2 & 101,8 & 107,1 & 4,04 & 0,0001 \\
\hline Wielka Brytania & 92,7 & 98,2 & 105,6 & 103,9 & 10,23 & 0,0001 \\
\hline UE & 97,1 & 97,9 & 103,6 & 102,4 & 39,95 & 0,0001 \\
\hline
\end{tabular}

Źródło: obliczenia własne na podstawie danych: (Zintegrowany..., 2017).

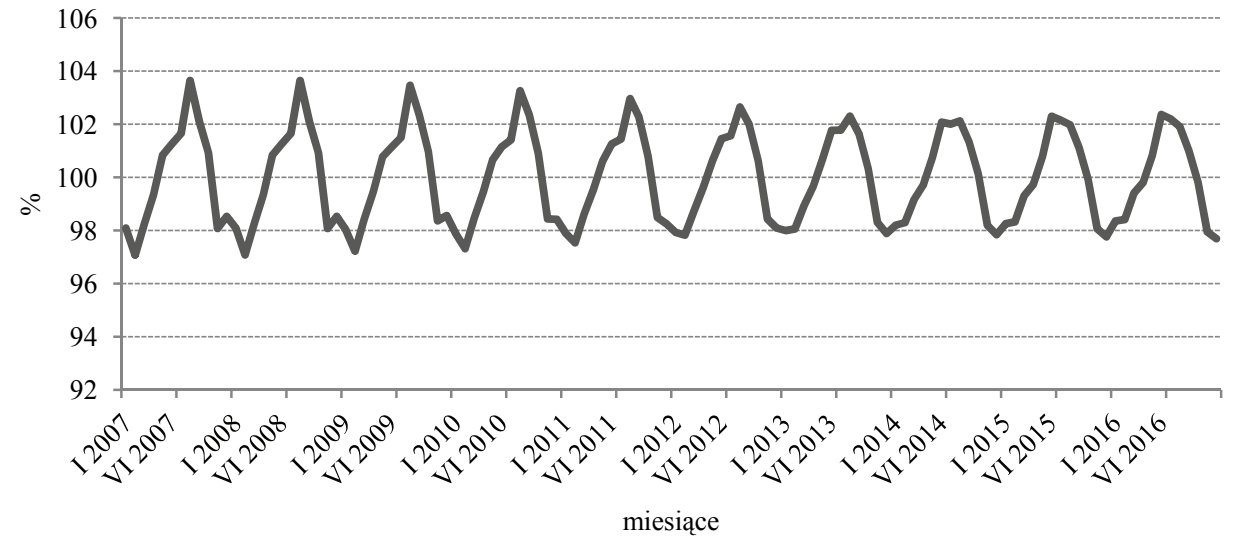

Rys. 3. Zmiany sezonowe cen mięsa brojlerów kurzych ogółem w UE w latach 2007-2016

Fig. 3. Seasonal fluctuation of broiler chicken meat prices all-in EU in years 2007-2016

Źródło: obliczenia własne na podstawie danych: (Zintegrowany..., 2017). 


\section{K. Utnik-Banaś}
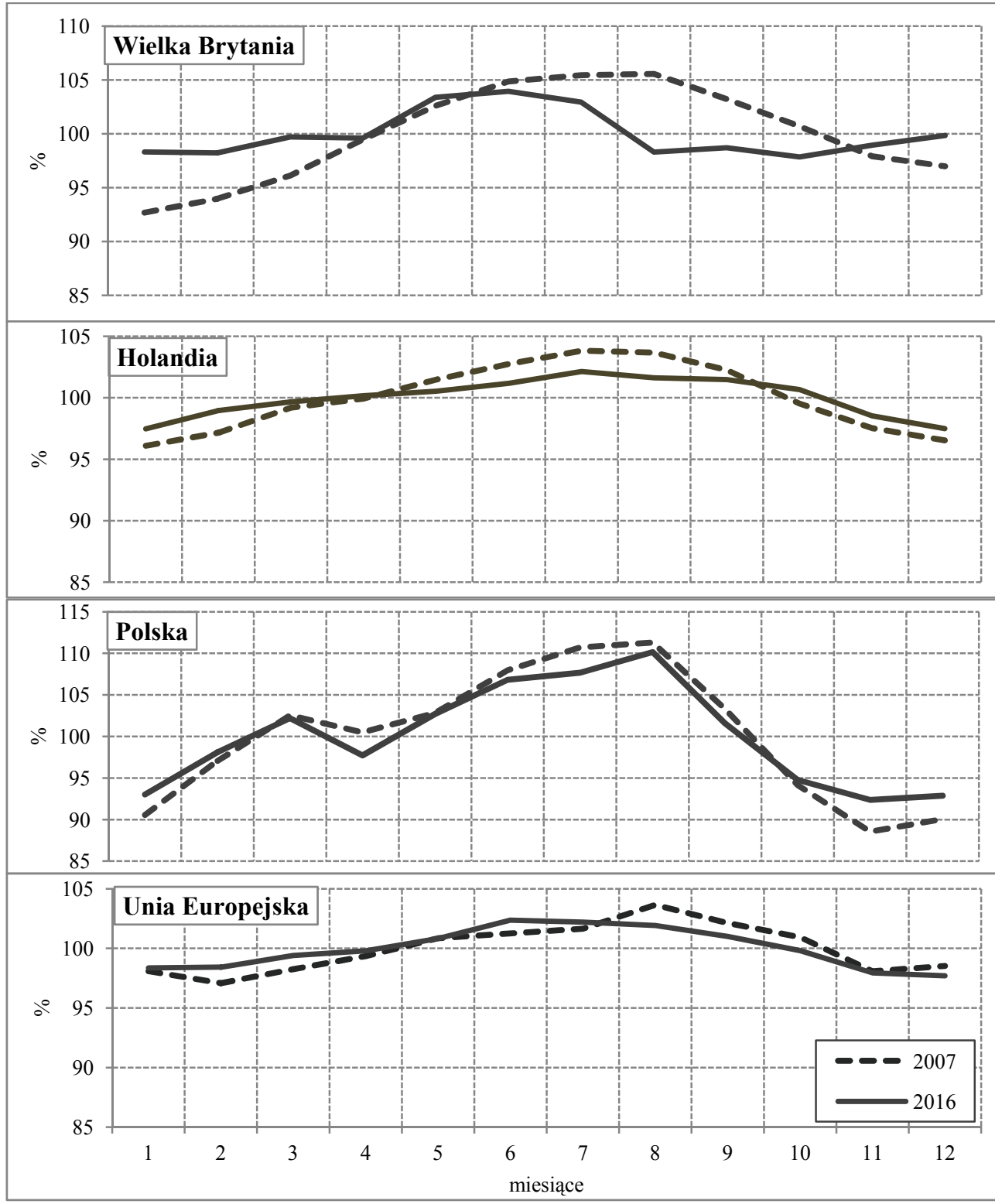

Rys. 4. Zmiany wzorca sezonowości cen mięsa kurcząt brojlerów w wybranych krajach oraz ogółem w UE w latach 2007 i 2016

Fig. Changes of seasonal pattern of broiler chicken meat prices in chosen EU countries and all-in EU in years 2007, 2016

Źródło: obliczenia własne na podstawie danych: (Zintegrowany..., 2017) 
W ogólnej zmienności cen wahania przypadkowe stanowiły średnio 5,4\%, sezonowe $42,3 \%$, a cykliczne $52,3 \%$ (tab. 3). W horyzoncie jednego miesiąca udział zmian przypadkowych wynosił $22,7 \%$, sezonowych $55,1 \%$, a cyklicznych $22,2 \%$. W horyzoncie sześciu miesięcy udział zmian przypadkowych zmniejszał się do 1,9\%, wzrastał udział zmian cyklicznych do 43,1\%, a sezonowych wynosił 55,0\%.

Tabela 3. Udział zmian przypadkowych sezonowych oraz cyklicznych w ogólnej zmienności cen mięsa kurcząt brojlerów w UE w zależności od horyzontu zmian (w \%)

Table 3. Share of irregular, seasonal and cyclical fluctuations in total variability of chicken broiler meat prices in depending on the horizon of change

\begin{tabular}{l|ccc}
\hline \multirow{2}{*}{ Horyzont zmiany } & Rodzaj zmiany & Sezonowe \\
\hline 1 & 22,7 & Cykliczne & 55,1 \\
2 & 10,0 & 22,2 & 59,8 \\
3 & 5,4 & 30,3 & 60,7 \\
4 & 4,1 & 33,9 & 60,0 \\
5 & 2,5 & 35,9 & 58,8 \\
6 & 1,9 & 38,7 & 55,0 \\
7 & 1,9 & 43,1 & 46,8 \\
9 & 2,2 & 51,3 & 23,0 \\
11 & 1,7 & 74,8 & 3,6 \\
12 & 1,7 & 94,8 & 0,1 \\
Średnio & 5,4 & 98,2 & 42,3 \\
\hline
\end{tabular}

Źródło: obliczenia własne na podstawie danych: (Zintegrowany..., 2017).

\section{Dyskusja}

Zmienność cen produktów rolnych ma duże znaczenie zarówno dla producentów rolnych w kontekście optymalizacji funkcji celu produkcji, jak również konsumentów dokonujących wyboru zakupu określonych produktów. Analiza poziomu cen stanowi jednocześnie pośredni sposób oceny efektywności rynku (Figiel, 2002). Często za teoretyczny fundament oceny cenowej efektywności towarowych rynków w agrobiznesie przyjmuje się prawo jednej ceny. Prawo to dotyczy wolnego przepływu dóbr i informacji i związanego z tym kształtowania się cen w czasie i przestrzeni. W klasycznym ujęciu prawo jednej ceny wskazuje, że przy spełnieniu określonych warunków, wszystkie ceny w obrębie danego rynku są jednolite po uwzględnieniu kosztów zwiększenia użyteczności miejsca, czasu i formy produktu (Kohls i Uhl, 1990). Wyniki pracy wskazuja na występowanie znacznych różnic pomiędzy krajami członkowskimi objętych wspólnym rynkiem unijnym. Ceny mięsa brojlerów w latach 2007 - 2016 w Niemczech (średnio 250 Euro/100kg) były prawie dwukrotnie wyższe niż w Polsce (średnio 132 Euro/100kg). Czyżewski i Danilczuk (2008) wskazywali, że korzystny poziom cen drobiu w Polsce ukształtował się przede wszystkim w wyniku niskich kosztów wytwarzania w porównaniu z krajami Europy Zachodniej, zwracają jednocześnie uwagę, że nie jest to element 
przewagi długookresowej i mechanizmy rynkowe wcześniej czy później doprowadzą do zrównania się różnic pomiędzy krajami Wspólnoty. Na poziom cen żywca brojlerów w Polsce w okresie przed przystapieniem do Unii Europejskiej decydujący wpływ miały czynniki kosztowe, takie jak: cena piskląt, paszy i pszenicy, zaś w okresie po akcesji wzrost wpływu czynników popytowych, w tym sezonowy wzrost cen związany ze zwiększonym popytem na mięso drobiowe w miesiącach letnich (Utnik-Banaś i Żmija, 2016). Hamulczuk (2014) analizując zmienność cen w kontekście ryzyka cenowego podkreśla, że szeregi czasowe cen powinny być „oczyszczone” z przewidywalnych składników zmienności to jest wahań sezonowych oraz trendów długookresowych.

\section{Wnioski}

$\mathrm{Na}$ podstawie uzyskanych wyników badań można sformułować następujące spostrzeżenia i wnioski:

1. Pomimo wspólnego rynku na obszarze Unii Europejskiej istnieje znaczne zróżnicowanie przestrzenne cen mięsa kurcząt brojlerów pomiędzy krajami członkowskimi. W okresie 2007-2016 najwyższe ceny (średnio powyżej 240 występowały w Niemczech, Finlandii i na Cyprze, a najniższe (poniżej 150 Euro/100 $\mathrm{kg}$ ) miały miejsce w Polsce, Wielkiej Brytanii i Bułgarii.

2. Ceny mięsa kurcząt brojlerów podlegały wahaniom nieregularnym, sezonowym i cyklicznym, natomiast zakres $\mathrm{i}$ istotność tych wahań były znacznie zróżnicowane w poszczególnych krajach. Większe zróżnicowanie cen w czasie występowało w krajach, gdzie poziom cen był niższy, natomiast w krajach, gdzie poziom cen był wysoki, ceny charakteryzowały się również większą stabilnością.

3. Ceny mięsa kurcząt brojlerów w UE cechuje sezonowość. Wyższe ceny występują latem (z kulminacją czerwiec - sierpień), a niższe późną jesienią i zimą (listopad luty). Kraje o największych amplitudach zmian sezonowych to: Polska (średnio 20\%), Portugalia (15\%), Belgia (11\%) i Wielka Brytania (10\%).

\section{Literatura}

Borkowski, B., Krawiec, M. (2009). Ryzyko cenowe na rynku surowców rolnych. W: Zarządzanie ryzykiem cenowym a możliwości stabilizowania dochodów producentów rolnych - aspekty poznawcze i aplikacyjne. Red. M. Hamulczuk, S. Stańko.

Czyżewski, A., Danilczuk, J. (2008). Konkurencyjność polskiego rynku drobiu i jaj w wymianie z Unią Europejską. Rocz. Nauk. SERiA, 4(10), 56-61.

Czyżewski, A., Kryszak, Ł. (2015). Relacje cenowe w rolnictwie polskim a dochodowość gospodarstw rolnych i gospodarstw domowych rolników. ZN SGGW Problemy Rolnictwa Światowego, 15(3), 17-29.

Dybowski, G. (2015). Handel zagraniczny drobiem. Biuletyn Informacyjny ARR, 2, 10-13.

FAOSTAT (2017). http://faostat3.fao.org/home/E

Figiel, S. (2002). Cenowa efektywność rynku towarowego na przykładzie zbóż w Polsce. Wydawnictwo Uniwersytetu Warmińsko-Mazurskiego, Olsztyn.

Figiel, S., Hamulczuk, M., Klimkowski, C. (2012). Metodyczne aspekty analizy zmienności cen oraz pomiaru ryzyka cenowego na towarowych rynkach rolnych. Komunikaty, Raporty, Ekspertyzy, 559, IERiGŻ-PIB, Warszawa

Hamulczuk, M., Rembisz, W. (2008). Rynkowe uwarunkowania ryzyka cenowego i dochodowego. W: Zarządzanie ryzykiem cenowym a możliwości stabilizowania dochodów producentów rolnych - aspekty poznawcze i aplikacyjne. M. Hamulczuk i S. Stańko (red.). IERiGŻ-PIB, Warszawa, 148, 47-81. 
Hamulczuk, M., Stańko, S. (2009). Prognozowanie cen podstawowych produktów na przykładzie pszenicy i żywca wieprzowego. W: Zarządzanie ryzykiem cenowym a możliwości stabilizowania dochodów producentów rolnych - aspekty poznawcze i aplikacyjne. Red. M. Hamulczuk, S. Stańko. IERiGŻ-PIB, Warszawa, 148, 181-208.

Hamulczuk, M. (2014). Ryzyko cenowe a zmienność cen i relacji cenowych w rolnictwie. Roczniki Naukowe Ekonomii Rolnictwa i Rozwoju Obszarów Wiejskich, 101(4), 54-67.

Idzik, M. (2009). Analiza struktury szeregów czasowych cen produktów rolnych. W: Zarządzanie ryzykiem cenowym a możliwości stabilizowania dochodów producentów rolnych - aspekty poznawcze i aplikacyjne. Red. M. Hamulczuk, S. Stańko. IERiGŻ-PIB, Warszawa, 148, 15-47.

Kłusek, K. (2015). Zmiany cen tuszek kurczaków w wybranych krajach Unii Europejskiej w latach 2009-2015. ZN SGGW Problemy Rolnictwa Światowego, 15(3), 61-69.

Kohls, R.L. Uhl, J.N. (1990). Marketing of agriculture products. Macmillan Publishing Company, 146-148.

Kot, S., M., Jakubowski, J. Sokołowski, A. 2011. Statystyka. Wydawnictwo Difin, Warszawa, 335-357.

Mottet, A., Tempio, G. (2017). Global poultry production: current state and future outlook and challenges. World's Poultry Science Journal, 73(2), 245-256.

Olszańska, A. (2009). Zmiany na rynku żywca drobiowego po wejściu Polski do Unii Europejskiej. Rocz. Nauk SERIA, 11(3), 270-274

Stańko, S. (red.) (2013). Prognozowanie w agrobiznesie. Teoria i przykłady zastosowania, Wydawnictwo SGGW, Warszawa.

Szymańska, E. (2012). Zmienność koniunktury na rynku trzody chlewnej w Polsce. Roczn. Nauk. SERiA, 14(1), $524-528$

Utnik-Banaś, K., Żmija, J. (2016). Wpływ wybranych czynników na cenę żywca brojlerów w latach 1995-2015. ZN SGGW Problemy Rolnictwa Światowego, 16(2), 344-352.

Zintegrowany System Rolniczej Informacji Rynkowej (2017). Pobrane kwiecień 2017 z: http://www.minrol.gov. $\mathrm{pl} / \mathrm{pol} /$. 